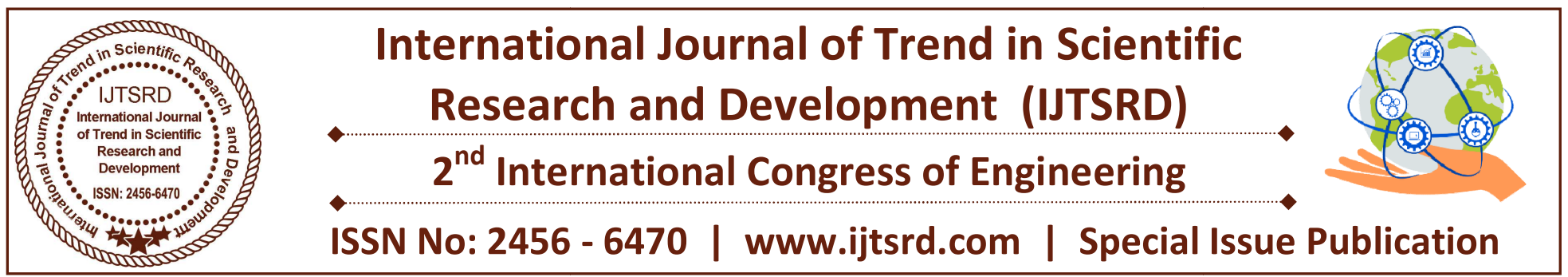

\title{
Improvement of the production process through the application of the simulation technique
}

\author{
${ }^{1}$ González Torres Arturo, ${ }^{1}$ Ramirez Castañeda Armando I., ${ }^{1}$ Ricardez González Dalia K., \\ ${ }^{1}$ Fernández López Susana. Y, ${ }^{2}$ Martínez Muñoz María F. \\ ${ }^{1}$ Tecnológico Nacional de México \\ ${ }^{2}$ Zinbend S. A. de C.V. \\ Instituto Tecnológico de Tláhuac II
}

\begin{abstract}
The present research presents the results obtained from a practical study regarding the improvement of the production process through the application of the simulation technique. A $90 \%$ reliability and $10 \%$ error were used for the time-lapse study. For the analysis of the production process ProModel ${ }^{\circledR}$ specialized software was used in its test version. The results obtained in the research were that the simulation model behaves similar to the actual production process; Likewise, the productivity of the production process was $2.33 \%$.
\end{abstract}

Keywords: Production process, improvement, simulation.

The macroeconomic environment facing firms is increasingly uncertain. At the same time, from the point of view of the company itself, it has to face greater competition, and relate to customers less and less captive with a high degree of information about the market. This results in an irreversible decline in results and an uncertainty that involves high levels of risk. Faced with this situation arises the need to manage new instruments to improve the strategic planning of companies (Fullana and Urquía, S / A). Labarca and Zulia (2007) argue that, at present, in the business sector there is a need to be more and more competitive, which forces organizations to analyze their processes to obtain a better quality that allows them to meet the needs and customer expectations. Business competitiveness, in the context of globalization, requires organizations to be sustainable in national and international markets to have a more efficient and effective administration of the productive processes of their financial, human and technological resources, among others. Gaither and Frazier (2000) point out that the leading organizations become more austere and more agile, and increasingly rely on their lean, reliable and efficient operation which should be managed in the best possible way if they are to make sound decisions about the activities of production systems.

The origins of the simulation lie in the theory of statistical sampling and analysis of complex probabilistic physical systems. The common aspect of both is the use of numbers and random samples to approximate solutions (Ferreiro, Azcárate and Mallor, 2011). Facultat d'Informàtica de Barcelona (S / A) argues that the origins of the simulation go back to World War II when mathematicians, J. V Neumann and S. Ulam, had the challenge of solving a complex problem related to behavior of the neutrons. Experiments based on trial and error were very expensive and the problem was too complicated to be addressed by analytical techniques. Mosterín (1987) argues that the use of a model allows us to elaborate a system theory, that is, to adequately describe the present functioning of the system, to explain what happened in the past and to predict what will happen in that system in the future, having present the limitations of the same with respect to the realized or represented with the model. The approach they chose is based on the use of random numbers and 
probability distributions. The method developed was called Monte Carlo Method by the generation of random numbers and the game of roulette. D'Arthenay (2015) mentions that computer use in simulation began with the PACER program in 1966, and its increasing use in the simulation of industrial processes has been made possible by the development of numerical techniques and the use of new languages of simulation.

The process of experimenting with a model is called simulation. The process of designing the experiment plan to make the best decision is called optimization. If the experiment plan is carried out with the sole purpose of learning to drive the system, then it is called training or training (Tarifa, S / A). Harrington and Tumay (1999) point out that the simulation allows to experiment with a model of the system to better understand the processes, in order to improve the activity in the companies. Harrell and Tumay (1995) mention that simulation is a means of experimenting with a detailed model of a real system to determine how the system will respond to changes in its structure or environment. Arahal, Berenguel and Rodríguez (2006) argue that simulating consists of using a model to calculate and provide a certain output variable in order to produce similar evolutions with identical stimuli. Law and Kelton (2007) indicate that, in the general sense, the simulation deals with the study of dynamical systems in time. Kelton, Sadowski and Sturrock (2008) mention that computer simulation refers to methods for studying a wide variety of real-world systems models by numerical evaluation using software designed to mimic the operations or characteristics of the system, often in the course of time. Cabrera (2009) cites that the simulation is the discipline of the design and fictitious representation of real situations, by means of mathematical and technological elements in which it is experimented through a model that constitutes an abstraction of the reality; with the aim of understanding the behavior of the system and evaluating different types of strategies for its best operation. Soto (2010) points out that the simulation is the imitation of a dynamic system through a computational model. The experimentation on computational model, is sought to evaluate the operational characteristics of the system (or subsystem) that this being represented by the model. Experimentation on the model should help the understanding of the behavior of the system and in this way contribute to the decision making, which could lead to improve the performance of the system under study. Sánchez, Ceballos and Sánchez (2015) mention that the simulation of systems is an alternative to know in a correct way the critical points that can have the production processes of a company and with these model solutions that increase efficiency and reduce the times in the different activities carried out during the production of an article or the provision of a service. Olivas (S / A) mentions that process simulation is one of the greatest tools of industrial engineering, which is used to represent a process through another process that makes it much simpler and more understandable.

Álvarez and García (S / A) mention that simulation is becoming a necessary instrument in any area of work. Montoya (2007) argues that simulation as a support tool within the decision-making process can be used for the planning and improvement of different areas within the business scope of manufacturing and services, such as:

Inventory system,

$>$ Waiting line systems,

$>$ Manufacturing system,

$>$ Service industry,

$>$ Transport and distribution systems

Prieto (2015) argues that the objectives for which the simulation is used:

Analyze and study the impact on the overall performance of the system of small changes made to some of its components.

$>$ Changes in the organization of a company.

$>$ Suggest potential improvements in performance.

$>$ Illustrate and facilitate the understanding of the results obtained through analytical techniques (can also be used with pedagogical vision).

Experiment with operating conditions that could be dangerous or high in the real system.

Zapata and Lizardi (2013) point out that the use of simulation is an optimal and economic means to make changes in the actual processes in a maquiladora company. Therefore, it can be affirmed that the 
simulation is fundamental for the construction of models used for the optimization of processes.

At the moment there are different programs that help the simulation of processes, among which are: QUEST, Flexsim, Arena, Witness, EM-Plant, Showflow, Enterprise Dynamics, Simul8, ProModel, E-Factory (Martínez, Bernabé, Hormaechea, Mínguez, and Ispizua, S / A). García, García, and Cárdenas (2006) argue that this commercial software is one of the most used in the market, which focuses on manufacturing processes of one or several products, transformation assembly lines, among others. Salazar (S / A) argues that ProModel is a magnificent and complete program of simulation of industrial processes, since it allows to simulate any logistic or manufacturing process, as well as strategic situations, and also to simulate the different processes of material handling. García, Eguia and Izaguirre (2015) mention that the choice of ProModel as a Simulation technology tool, has a great advantage because it is an interactive graphic software, which allows engineering students to adapt easily to their use and generation of practices.

The origins of ProModel go back in the year 1976 . The plant was Ford Motor Company, which was developing a new car model. The challenge was to determine the right balance between machine capacities, buffering and allocation of resources to meet production levels defined for each production line. Of course, keeping the minimum cost of production. (Harrell, S / A) mentions that this was his first experience in computer simulation. At that time, simulation models were usually programmed by computer programmers in Fortran, a scientific programming language. However, there were mainly two drawbacks to this approach: (1) the simulation studies took too long (up to one or two years to program and revise completely, too late to deliver useful responses) and (2) programmers were not engineers and therefore, they normally had difficulty understanding the simulated process and knowing what solutions were feasible (Harrell, S / A).

ProModel ${ }^{\circledR}$ software customers include: Pfizer, Lockheed Martin, U.S. Army, TSA, Merck, West Point, General Dynamics, Medtronic, Baxter BioPharma, Driscoll's. Federal Express, Northrop Grumman, Boeing, MIT, U.S. Air Force, Nestlé Purina (Pinto, 2013). Trujillo, Vallejo and Becerra (2010) used the simulation to model a call center with
ProModel ${ }^{\circledR}$, which allows the identification of goodness of fit and homogeneity tests in order to formulate improvement proposals for system productivity. They raised the requirement for new staff and identified bottlenecks. Morales, Rojas, Hernández, Morales, Rodríguez and Pérez (2013) conducted a study with the supply chain model developed in ProModel ${ }^{\circledR}$ software, which achieves the representation of a supply chain according to the structure and behavior require for the experimentation of possible improvements with lean manufacturing. The parameters of the model subject to variation refer to reductions of waste in the process of the chain. Taddei, Rodríguez and Ruiz (2013) showed how the application of the simulation of systems allows to make more efficient the use of the resources, to reduce the waiting times and to give better attention, in this case to the aspirants to enter the Universidad of Sonora.

\section{General objective}

Improve the production process by applying the simulation technique

\section{Specific objectives}

$>$ Understand the contextualization of the topic.

$>$ Know the existing models to evaluate the quality of a production process.

$>$ Calculate the representative sample using 90\% reliability.

$>$ Build the simulation model using specialized ProModel ${ }^{\circledR}$ software.

$>$ Analyze the results obtained from the construction of the simulation.

$>$ Evaluate the results obtained from the simulation analysis.

\section{Justification}

The project will be carried out in order to make known the benefit of using the simulation technique. Many companies are unaware of this type of technique, which helps not only understand a real model or system, but also, the simulation helps to make the best decision regarding the performance of a model or system.

The project will show a simulation of the production process, which will identify the areas of work and the 
composition of the entire process. You have the information required to do the respective analysis of the manufacturing process as resources, elements, manufacturing times and the various activities.

\section{Method Description}

The study was carried out in 7 stages as shown in figure 1.

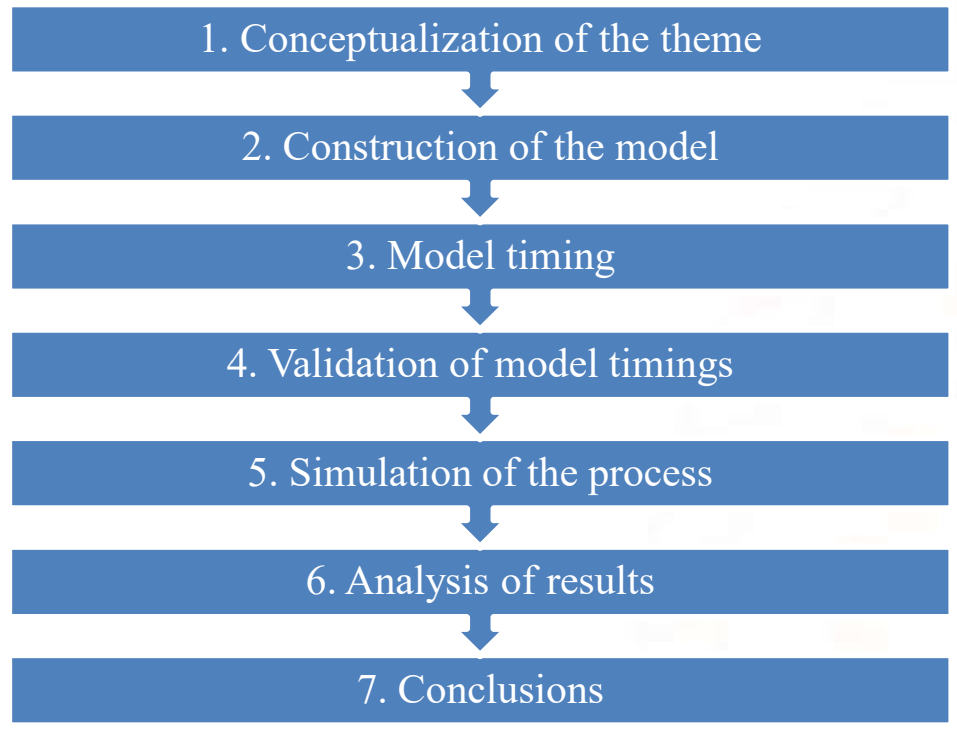

Figure 1. Example of methodological steps.

Conceptualization of the theme. At this stage a bibliographic search of the subject was made, in order to better understand the theme.

Construction of the model. In this phase the process to be analyzed was observed. In order to better understand how the production process is formed, random visits were made in order to better understand the study.

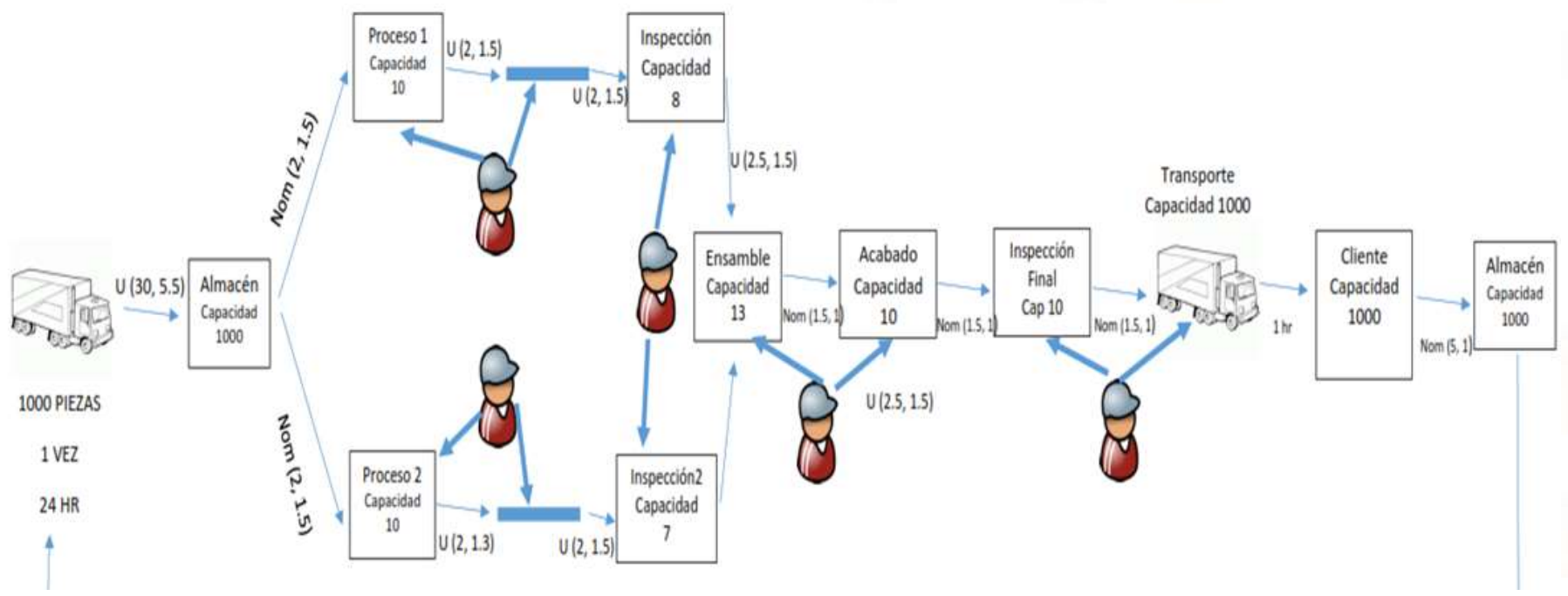

Example of the production process 
- Model timing. Once the production process was studied, samples of each activity were made. We used the formula of Dr. Bolaños (2012), who proposes the following formula for an infinite sample:

$$
n=\frac{Z_{\alpha}^{2} * p^{*} q}{i^{2}}
$$

Where:

n: sample size.

$\mathrm{z}$ : value corresponding to gauss distribution, $90 \%$ $(1,645)$ was used for the study.

$\mathrm{p}$ : expected prevalence of the parameter to be evaluated, if not known $(\mathrm{p}=0.5)$, which increases the sample size

$\mathrm{q}: 1-\mathrm{p}($ if $\mathrm{p}=70 \%, \mathrm{q}=30 \%)$

i: error expected to be committed if it is $10 \%, \mathrm{i}=0$.
The formula developed is as follows:

$$
n=\frac{(1.645)^{2} * 0.5 * 0.5}{(0.10)^{2}}=67.65 / 0.01=67.65 \approx 68
$$

The study indicated that for the investigation of the production process, using $90 \%$ of reliability and $10 \%$ of allowed error, 68 observations or time takings will be needed for the investigation.

Also, once it is known how many time takers should be made for the investigation, it was carried out. Figure 3 represents an example of the timing of each activity.

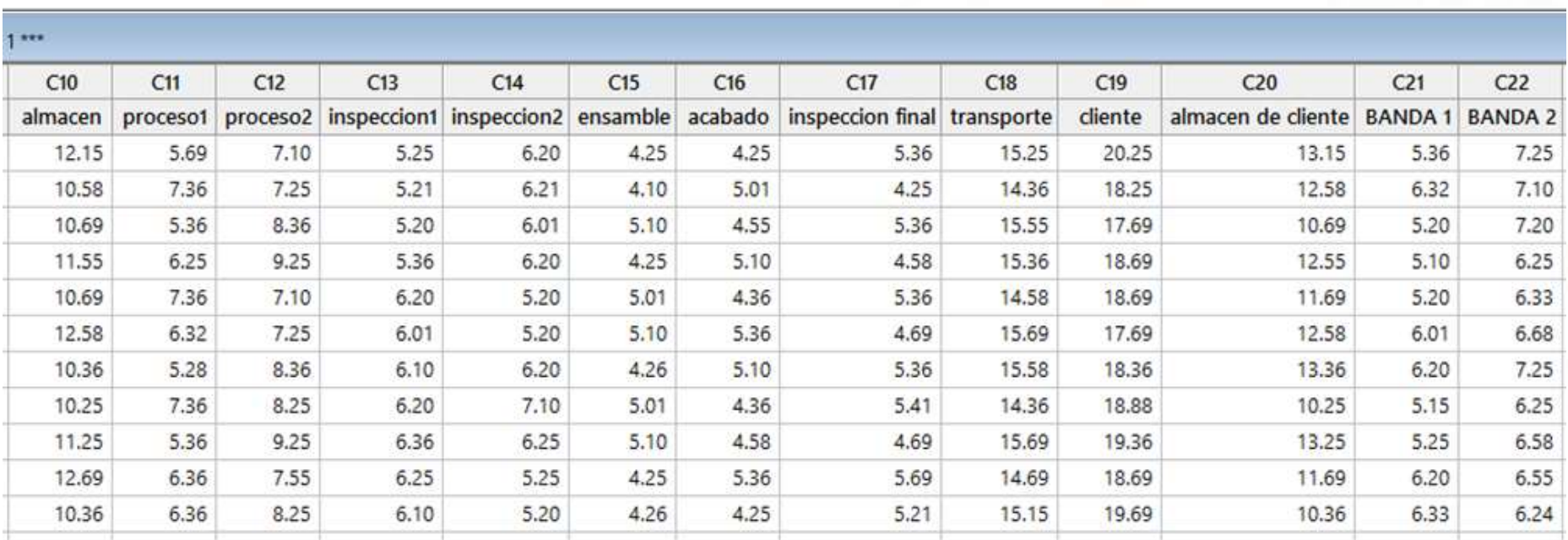

Figure 3. Example of model timings

- Validation of model timings. At this stage it was validated whether sixty-eight preliminary samples were more than sufficient for the study. All samples of each activity of the production process were validated, the formula used was as follows:

$$
n=\left[\frac{Z * \sigma}{e^{2}}\right]^{2}
$$

Where:

n: number of samples needed for the study.

$\mathrm{Z}$ : value corresponding to the gauss distribution, for the investigation $Z=95 \%$, which is equal to 1.96 . $\sigma$ : standard deviation of the preliminary sample.

i: error expected to be committed in the study. The error is set to integer.

It is worth mentioning that, if the result of the formula is smaller than the size of the preliminary sample, the study is considered good or sufficient. Otherwise, if the number of the formula is greater than the size of the preliminary sample, the study is not suffering, which means that samples are missing to perform for the study to be complete.

The development of the formula for the warehouse activity is as follows: 
$n=\left[\frac{1.96 * 0.915}{5}\right]^{2}=\left[\frac{1.7934}{5}\right]^{2}=(0.3586)^{2}=0.1286 \approx$ that those sixty-eight times are enough.

The study indicated that using $95 \%$ reliability, a 5 of allowed error and a standard deviation of 0.915 for the activity of the warehouse, will be needed 0.1286 samples, if rounding this number to the greater integer, would be a sample of time. Which means that with a time-out is more than enough, the preliminary
Simulation of the process. In this phase the model was built with time in ProModel ${ }^{\circledR}$ specialized software in its student version. Figure 4 shows an example of the model constructed with specialized software.

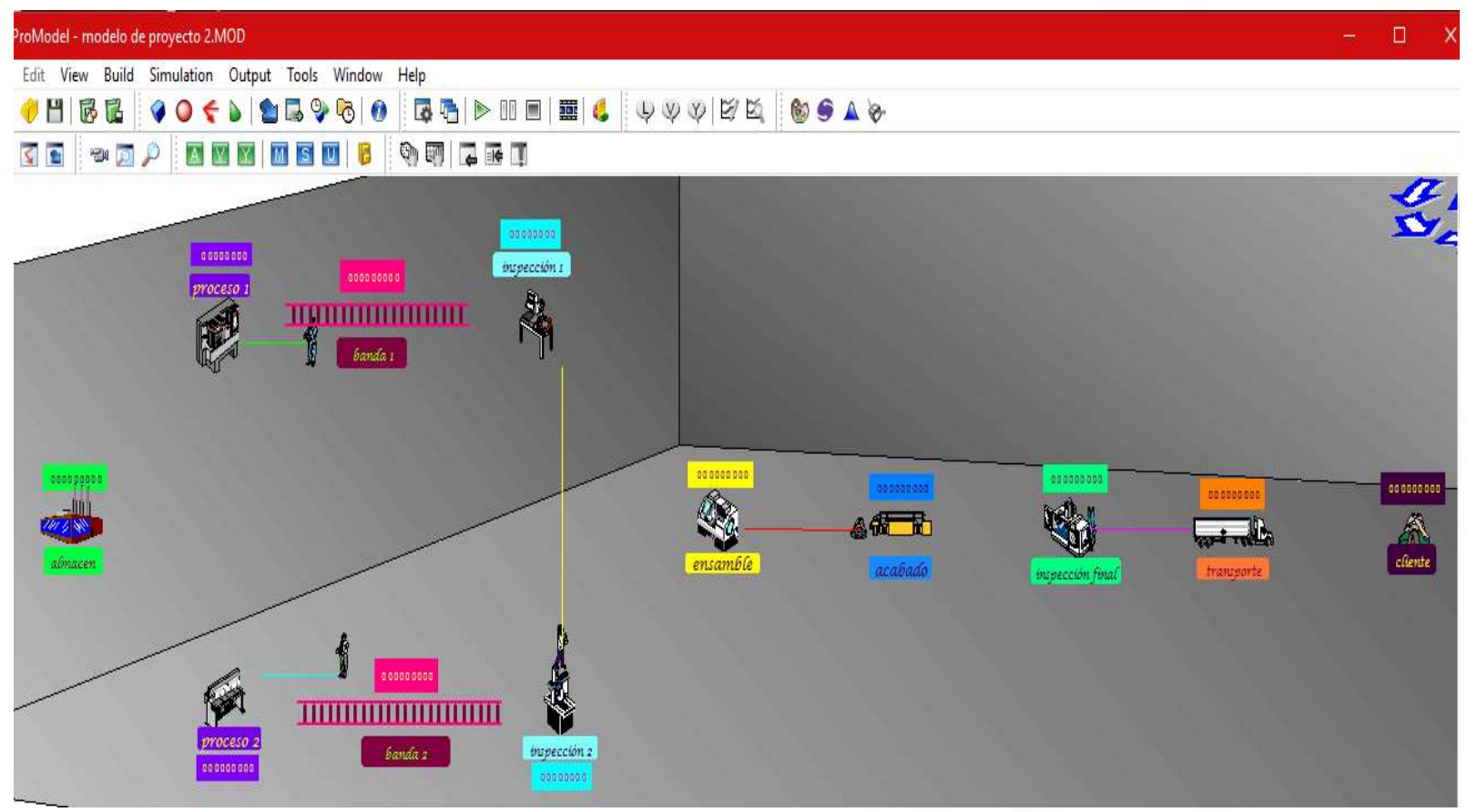

Figure 4. Example of model built in ProModel ${ }^{\circledR}$ software.

- Analysis of results. Once the model was made in ProModel ${ }^{\circledR}$ software, the results of the production process were examined. Figure 5 represents an example of the results of specialized software.

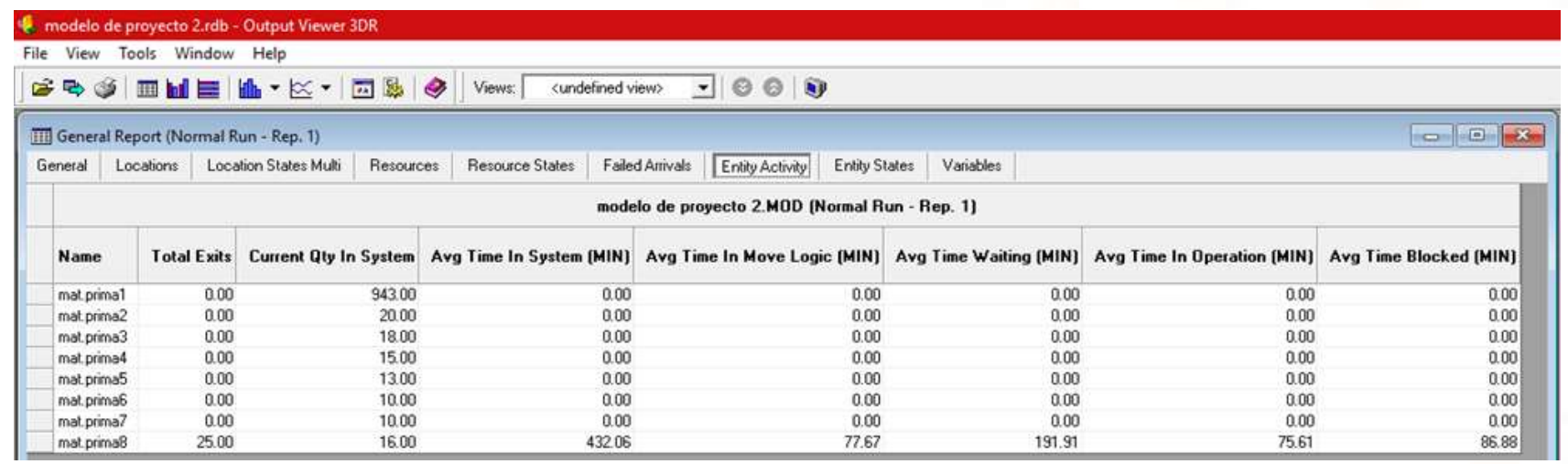

Figure 5. Example of the results of the production process

Continuing with the analysis of the results, Table 1 represents the indicators of the production process. 
Table 1. Example of the results of the production process.

\begin{tabular}{|c|c|}
\hline Failed Parts & 0 \\
\hline $\begin{array}{c}\text { Parts in the } \\
\text { system }\end{array}$ & 1045 \\
\hline \hline Successful parts & 25 \\
\hline Total of parts & 1070 \\
\hline
\end{tabular}

Continuing with the analysis of the production process, the productivity of the system is calculated:

$$
\begin{aligned}
\text { Productivity: } & \frac{\text { Successful parts }}{\text { Total of parts }}: \frac{25}{1070} \times 100 \% \\
& =2.33 \%
\end{aligned}
$$

The above formula shows that the productivity of the analyzed process is $2.33 \%$, which represents a pauper result. The present investigation allows to observe that the use of the simulation helps to know the operation of a process.

\section{Conclusions}

It was possible to improve the production process by applying the simulation technique, which shows that the general objective was achieved.

Also, it was possible to understand the contextualization of the subject and the importance of the technique of simulation applied in the processes. In addition, it was possible to identify the main components and activities of the production process, which went from general to specific.

There are different programs specialized in simulation, all softwares are good provided you have the knowledge and skills to manipulate them. In this research, ProModel® software significantly helped the understanding and analysis of the production process to be studied.

A more comprehensive study is recommended by increasing the minimum confidence interval to $95 \%$ confidence, with this the maximum allowed error will be reduced and even more accurate data will be obtained.

\section{References}

1) Álvarez, M. E. y García, R. M. (S/A). La simulación en la industria. Importancia. Simulación de los Procesos de Producción en los Ingenios Azucareros. Universidad Técnica del Norte. Ibarra, Ecuador.

2) Arahal M., Berenguel M. y Rodríguez F. (2006). Técnicas de predicción con aplicaciones en Ingeniería. Sevilla: Publidisa. ISBN 84-472-1060-X.

3) Bolaños Rodríguez, E. (2012). Muestra y Muestreo. Asignatura: Estadística para el Desarrollo Tecnológico. Área Académica: Gestión Tecnológica. Escuela Superior e Tizayuca. Universidad Autónoma de Hidalgo.

4) Cabrera Riaño, M. C. (2009). Propuesta de manual de prácticas de simulación de sistemas discretos con ProModel ${ }^{\circledR}$, para el desarrollo de ejercicios aplicados en diferentes asignaturas de la carrera de Ingeniería Industrial en la Pontificia Universidad Javeriana. Carrera de Ingeniería Industrial. Departamento de Procesos Productivos. Facultad de Ingeniería. Pontificia Universidad Javeriana. Bogotá D.C.

5) D’Arthenay Bermúdez, D. H. (2015). Desarrollo de un simulador de procesos industriales bajo configuración Hardware-in-the-Loop para la práctica-enseñanza de control lógico y regulatorio mediante un PLC. Facultad de Ingeniería, Departamento de Ingeniería Eléctrica y Electrónica. Universidad Nacional de Colombia. Bogotá, Colombia.

6) Facultat d'Informàtica de Barcelona. (S/A). La simulación por ordenador. Facultat d'Informàtica de Barcelona.

7) Ferreiro, Azcárate y Mallor. (2011). Simulación del proceso productivo de INASA FOIL, S.A. Escuela Técnica Superior de Ingenieros Industriales y de Telecomunicación. Pamplona. España.

8) Fullana Belda, C. y Urquía Grande, E. (S/A). Los modelos de simulación: una herramienta multidisciplinar de investigación. Universidad Pontificia de Comillas. Madrid, España.

9) Gaither, N. y Frazier, G. (2000). Administración de Producción y Operaciones. $8^{\mathrm{a}}$ ed. México, International Thomson Editores, p. 15-22.

10) García Chi, R. I., Eguia Álvarez, A. y Izaguirre Cárdenas, G. E. (2015). Uso de la herramienta de software PROMODEL como estrategia didáctica en 
el aprendizaje basado en competencias de simulación de procesos y servicios. Revista TECTZAPIC, n. 1.

11) García Dunna, E., García Reyes, H. y Cárdenas Barrón, L. E. (2006). Simulación y análisis de sistemas con ProModel. Naucalpan de Juárez, Estado de México, México: Pearson Educación de México, SA de CV.

12) Harrell, C. (S/A). Los inicios de ProModel. Simulart.

13) Harrell, C. y Tumay, K. (1995). Simulation Made Easy. A Manager's Guide. Norcross, GA: Industrial Engineering and Management Press.

14) Harrington, H. J. y Tumay, K. (1999). Simulation modeling models. McGraw Hill New York. USA.

15) Kelton, W.D., Sadowski, R.P. y Sturrock, D.T. (2008). Simulación con Software Arena. $4^{\mathrm{a}}$ ed. México: Mc Graw-Hill, Inc.

16) Labarca, N. y Zulia, U. (2007). Consideraciones teóricas de la competitividad empresarial. Omnia, Vol. 13, No. 2, pp. 158-184.

17) Law, A. M y Kelton, D. (2007). Simulation modeling and analysis. Editorial McGraw Hill, U.S.A.

18) Martínez, R., Bernabé, M., Hormaechea, A., Mínguez, R. y Ispizua, R. (S/A). Simulación de procesos industriales: beneficios para la empresa. Asociación Española de Dirección e Ingeniería de Proyectos (AEIPRO).

19) Montoya Torres, J. (2007). Notas Técnicas Simulación Conceptos básicos sobre simulación de eventos discretos, 12-13.

20) Morales González, Á., Rojas Ramírez, J., Hernández Simón, L. M., Morales Varela, A., Rodríguez Sánchez, S. V. y Pérez Rojas, A. (2013). Modelación de la cadena de suministro evaluada con el paradigma de manufactura esbelta utilizando simulación. Científica, vol. 17, núm. 3, pp. 133-142. Instituto Politécnico Nacional. Distrito Federal, México.

21) Mosterín, J. (1987). Conceptos y teorías de la ciencia. 2a ed. Madrid, España: Alianza.

22) Olivas Tecero, N. (S/A). La importancia de la simulación de procesos en la industria. Universidad Nacional de Ingeniería-UNI-R.U.A.C.S.

23) Pinto Triana, W. J. (2013). Implementación de talleres basados en el software de simulación Flexim para la asignatura técnicas modernas de optimización. Escuela de Estudios Industriales y Empresariales. Facultad de Ingenierías Físico Mecánicas. Universidad Industrial de Santander. Bucaramanga. Santander, Colombia.

24) Prieto Renda, D. (2015). Integración de modelos de fabricación mediante simulación con herramientas informáticas y lean manufacturing. Escuela de Ingeniería Industrial. Universidad de Vigo. Pontevedra, España.

25) Salazar Guerrero, A. (S/A). Simulación de eventos. Centro Cultural ITACA S.C. Ciudad de México, México.

26) Sánchez, P.A., Ceballos, F. y Sánchez Torres, G. (2015). Análisis del proceso productive de una empresa de confecciones: modelación y simulación. Ciencia e Ingeniería Neogranadina, 25 (2), pp 137 150.

27) Soto, J. (2010). Laboratorios de simulación discreta. Colombia: Postergraph S.A.

28) Taddei, J.; Rodríguez, R., y Ruiz, J. (2013). Mejora del proceso de inscripciones en una Institución de Educación Superior mediante Simulación. Ingeniería Industrial, vol. 34.

29) Tarifa, E. E. (S/A). Teoría de Modelos y Simulación. Facultad de Ingeniería - Universidad Nacional de Jujuy. Argentina.

30) Trujillo, J., Vallejo, J., y Becerra, M. (2010). Metodología para la simulación de centros de llamadas. Caso de estudio. Studiositas, vol. 5, No. 3, pp. 117-137.

31) Zapata Rebolloso, A. y Lizardi Macías, S. (2013). Reducción de operaciones en una línea de producción. Memorias arbitradas del viii congreso de ingeniería industrial y de sistemas. Facultad de Ingeniería Mecánica y Eléctrica. San Nicolás de los Garza, Nuevo León, México. 